\title{
VITAMIN D - DIETARY INTAKE, SUPPLEMENTATION AND METABOLIC STATUS OF POLISH ADULTS
}

\section{SYLWIA KAMIŃSKA ${ }^{1}$, MAŁGORZATA PIKALA ${ }^{2}$, ELŻBIETA DZIANKOWSKA-ZABORSZCZYK ${ }^{2}$, WOJCIECH BIELECKI ${ }^{3}$, EWA RĘBOWSKA ${ }^{1}$, KRYSTYNA KOZAKIEWICZ ${ }^{4}$, PAWEL NADROWSKI ${ }^{4}$, WOJCIECH DRYGAS ${ }^{1,5}$, and MAGDALENA KWAŚNIEWSKA ${ }^{1}$}

\author{
${ }^{1}$ Medical University of Lodz, Łódź, Poland \\ Department of Preventive Medicine \\ ${ }^{2}$ Medical University of Lodz, Łódź, Poland \\ Department of Epidemiology and Biostatistics \\ ${ }^{3}$ Medical University of Lodz, Łódź, Poland \\ Department of Social Pathologies \\ ${ }^{4}$ Medical University of Silesia, Katowice, Poland \\ Division of Cardiology and Structural Heart Diseases \\ ${ }^{5}$ Cardinal Stefan Wyszyński University, Warsaw, Poland \\ Department of Epidemiology, Cardiovascular Disease Prevention and Health Promotion, Institute of Cardiology
}

\begin{abstract}
Objectives: Contrary to popular opinion on the preventive properties of vitamin D, results of previous studies have been inconclusive. The aim of this research was to evaluate the associations between the intake of vitamin D and metabolic abnormalities in a representative sample of Polish adults. Material and Methods: Within the framework of the Multi-Center National Population Health Examination Survey (referred to as WOBASZ), a random sample of 2381 adult residents of Poland (53.8\% of whom were women) was examined. All the study subjects were extensively reviewed, including 24-h dietary recall. The intake of vitamin D was assessed on the basis of dietary and supplements reviews. Metabolic abnormalities were evaluated using measurements of waist circumference (WC), blood pressure (BP), serum triglycerides (TG), high-density lipoprotein cholesterol (HDL-C) and fasting glycemia. Metabolic syndrome was defined according to the International Diabetes Federation. Results: Of all the study participants, about $4.4 \%$ of women and $2.6 \%$ of men declared a regular supplementation of vitamin D. Among women, a significant inverse correlation between vitamin D supplementation and the mean systolic BP was found $(\mathrm{p}<0.01)$. A more substantial relationship was noted after dividing the study subjects according to their body mass. Among obese men, there was a significant inverse relationship between vitamin $\mathrm{D}$ intake and the mean systolic BP $(p<0.01)$ and diastolic BP $(\mathrm{p}<0.05)$, as well as a positive correlation with HDL-C $(\mathrm{p}<0.05)$. Among obese women, a negative correlation was found between vitamin D supplementation and the mean systolic BP $(\mathrm{p}<0.01)$ and diastolic BP $(\mathrm{p}<0.05)$, and a positive correlation with TG $(\mathrm{p}<0.05)$. Among non-obese male subjects, a negative correlation between vitamin D intake and WC was observed. Conclusions: The obtained findings suggest that the correlation between vitamin D intake and metabolic abnormalities may depend on the obesity status. A higher vitamin D intake may reduce BP and increase HDL-C in obese subjects. The positive relationship between vitamin D intake and TG concentration in women needs further investigation. Int J Occup Med Environ Health. 2020;33(1):107-18
\end{abstract}

Key words:

adults, abdominal obesity, metabolic disorders, Polish, vitamin D supplementation, vitamin D intake

Funding: the WOBASZ and WOBASZ II studies were supported by the Ministry of Health of Poland (project entitled "National Program to Equalize Accessibility to Cardiovascular Disease Prevention and Treatment POLKARD," project manager: Prof. Grażyna Broda).

Received: November 13, 2018. Accepted: October 30, 2019.

Corresponding author: Magdalena Kwaśniewska, Medical University of Lodz, Department of Preventive Medicine, Żeligowskiego 7/9, 90-752 Łódź, Poland (e-mail: magdalena.kwasniewska@umed.lodz.pl). 


\section{INTRODUCTION}

Vitamin D is a fat-soluble vitamin deriving from dermal synthesis, dietary intake and supplements. Its few food sources include: fatty fish, eggs, fortified beverages and dairy products [1]. This prohormone has various functions in the human body, including bone mineralization, modulation of cell growth, regulation of calcium and phosphorus absorption from the gut, adjustment of the immunological system, and reduction of inflammation [2-4]. Therefore, it not only plays an important role in the pathogenesis of skeletal disorders but its impact on the risk of metabolic abnormalities also deserves special attention.

There has been increasing interest in proving the crucial role of vitamin $\mathrm{D}$ in the etiology of chronic metabolic conditions such as obesity and type 2 diabetes [5,6]. Recent studies have suggested that vitamin D may prevent cardiovascular diseases and risk factors of metabolic syndrome [3,7-10]. Nevertheless, the results of clinical trials are inconclusive [11-16]. In most, but not all [17-19] studies, vitamin D supplements have had a beneficial effect on the blood glucose level, lipids, body fat mass, blood pressure and oxidative stress mediators [20,21]. Interestingly, most studies have been conducted in western and tropical countries, where exposure to sunlight is significant $[3,4,10,16,22]$.

Little is known about the relationship between vitamin D intake and metabolic profiles in countries with relatively low insolation. Therefore, the authors decided to assess the correlation between vitamin $\mathrm{D}$ intake and the prevalence of metabolic abnormalities in a representative sample of adults in Poland.

\section{MATERIAL AND METHODS}

The Ethical Committee of the Institute of Cardiology in Warsaw approved the study protocol. Informed written consent was obtained from each participant.

The study sample consisted of randomly selected adult inhabitants of 3 large administrative districts in Poland (Łódź, Lublin and Lower Silesian voivodeships), partici- pating in the Multi-Center National Population Health Examination Survey (WOBASZ 2003-2005 and WOBASZ II 2013-2014). These research projects were carried out by the National Institute of Cardiology in Warsaw in cooperation with 5 medical universities. For both surveys, an independent random sample was drawn from the national population register. The 2-stage sampling scheme covered the whole territory of Poland and was stratified according to province and commune types. The study goals, methods and design used in these surveys were described in previous publications [23,24]. After excluding pregnant women and subjects with missing data on the required questions, the final study sample consisted of 2381 subjects (1282 women and 1099 men) aged 20-74 years.

All procedures were carried out by nurses and trained interviewers in the participants' houses or in selected out-patient clinics. The methodology closely followed the WHO MONICA protocol [25], and consisted of the following parts: a questionnaire interview, blood pressure, heart rate and anthropometric measurements, and blood sample collection.

The WOBASZ questionnaire included detailed questions on medical history, socio-economic factors, health knowledge, attitudes, lifestyle, nutrition, social support and depression. The employed interviewers were trained in the application, completion and codification of the questionnaire. In the present study, the following socio-demographic factors were considered: age, residential status, educational level, marital status, and smoking. The participants were divided into 3 categories of the place of residence according to the number of inhabitants in their living area (a "rural" area <8000 inhabitants; a small urban area 8000-40 000 inhabitants; a large urban area $>40000$ inhabitants). The association between vitamin D intake and metabolic disorders was evaluated on the basis of standardized questionnaire data, biochemical tests, physical examinations and anthropometric measurements. The consumption of food products and nutrients was as- 
sessed quantitatively using a $24-\mathrm{h}$ recall method applied by interviewers, making use of an album with over 200 photographs of the most frequently consumed dishes, products and drinks, established by the Food and Nutrition Institute in Warsaw. The energy from the consumed nutrients was assessed using the Polish Tables of Food Composition and Nutritional Value [26].

Weight, height, waist circumference (WC), and blood pressure were measured by trained nurses using standardized methods. Body weight was measured without shoes and top garments, to the nearest $0.1 \mathrm{~kg}$. Height was measured in the standing position without shoes, to the nearest $0.5 \mathrm{~cm}$. Waist circumference was measured at the level of the umbilicus, using an inextensible measuring tape, to the nearest $0.5 \mathrm{~cm}$. Blood pressure was measured 3 times on the right arm after 5 min of rest in the seating position by the automatic A\&D UA-631 device approved by the Association for the Advancement of Medical Instrumentation. The average from the second and third measurements was used for the analysis. Fasting glucose and blood lipid levels were determined on frozen serum samples in the central laboratory (the Institute of Cardiology, Warsaw) using enzymatic methods and automated procedures. Metabolic syndrome was defined according to the International Diabetes Federation (IDF), the American Heart Association, and the National Heart, Lung, and Blood Institute's definition as having 3 out of the following 5 factors:

1) central obesity (WC $\geq 94 \mathrm{~cm}$ in men and $\geq 80 \mathrm{~cm}$ in women);

2) triglycerides $(\mathrm{TG}) \geq 1.7 \mathrm{mmol} / \mathrm{l}(150 \mathrm{mg} / \mathrm{dl})$, or specific treatment for this lipid abnormality;

3) high-density-lipoprotein cholesterol (HDL-C) $<1.03 \mathrm{mmol} / \mathrm{l}(40 \mathrm{mg} / \mathrm{dl})$ in males, <1.29 mmol/l $(50 \mathrm{mg} / \mathrm{dl})$ in females, or specific treatment for this lipid abnormality;

4) systolic blood pressure (SBP) $\geq 130 \mathrm{~mm} \mathrm{Hg}$ or diastolic blood pressure (DBP) $\geq 85 \mathrm{~mm} \mathrm{Hg}$, or treatment of previously diagnosed hypertension;
5) fasting blood glucose (FG) $\geq 5.6 \mathrm{mmol} / \mathrm{l}(100 \mathrm{mg} / \mathrm{dl})$, or previously diagnosed and treated diabetes [27].

\section{Statistical analyses}

Continuous variables were examined for normality using the Kolmogorov test, and were presented as means and standard deviations. Categorical variables were presented as counts and percentages. To compare the frequency and to assess the statistical significance of the categories of qualitative characteristics in the analyzed groups, the $\chi^{2}$ test was implemented. Given that the potential correlates might differ between genders, all the analyses were performed separately for men and women. Pearson's correlation was used to evaluate the association between vitamin D consumption or supplementation and metabolic characteristics.

All $p$ values were 2-sided and $p<0.05$ was set as statistically significant. Statistical analyses were performed using Statistica Windows XP version 12.

\section{RESULTS}

The general characteristics of the study sample are shown in Table 1. Among all 2381 adults, 53.8\% were women, and the majority of the study participants were middle-aged subjects, aged 35-64 years. The percentage of current or former smokers was substantially higher among men as compared to women (70.3\% vs. $40.3 \%)$. About $32 \%$ of women and $37 \%$ of men declared regular physical activity at a level that could be defined as satisfactory. The analysis of the prevalence of metabolic risk factors revealed higher mean values of waist circumference, blood pressure, glucose and triglycerides plasma concentration in men than in women. Vitamin D dietary intake was also higher in men $(3.8 \pm 5.0 \mu \mathrm{g} /$ day $)$ $(2.5 \pm 2.9 \mu \mathrm{g} /$ day $)$, whereas women declared higher doses of vitamin D supplementation (Table 1). Regular vitamin D supplementation was declared by $4.4 \%$ of women and $2.6 \%$ of men. 
Table 1. Characteristics of the study participants - a representative sample of Polish adults participating in WOBASZ (2003-2005) and WOBASZ II (2013-2014) studies - in the study on the associations between vitamin D intake and metabolic abnormalities

\begin{tabular}{|c|c|c|}
\hline \multirow{2}{*}{ Variable } & \multicolumn{2}{|c|}{$\begin{array}{r}\text { Participants } \\
(\mathrm{N}=2381)\end{array}$} \\
\hline & $\begin{array}{c}\text { women } \\
(\mathrm{N}=1282)\end{array}$ & $\begin{array}{c}\text { men } \\
(\mathrm{N}=1099)\end{array}$ \\
\hline Age [years] $(\mathrm{M} \pm \mathrm{SD})$ & $45.9 \pm 15.4$ & $45.7 \pm 14.9$ \\
\hline \multicolumn{3}{|l|}{ Age group [\%] } \\
\hline $18-34$ years & 28.4 & 26.9 \\
\hline $35-64$ years & 56.8 & 59.9 \\
\hline$\geq 65$ years & 14.7 & 13.1 \\
\hline \multicolumn{3}{|l|}{ Residential status [\%] } \\
\hline small communes & 30.2 & 29.0 \\
\hline medium-sized communes & 29.1 & 28.8 \\
\hline large communes & 25.2 & 27.0 \\
\hline voivodship cities & 15.4 & 15.0 \\
\hline \multicolumn{3}{|l|}{ Tobacco smoking [\%] } \\
\hline current smoker & 22.7 & 40.5 \\
\hline former smoker & 17.6 & 29.8 \\
\hline never smoker & 58.4 & 29.3 \\
\hline \multicolumn{3}{|l|}{ Physical activity level [\%] } \\
\hline none & 39.0 & 34.0 \\
\hline rarely & 6.6 & 3.8 \\
\hline 1-3 times/week & 21.7 & 24.7 \\
\hline 4-7 times/week & 32.5 & 37.3 \\
\hline Body mass index $\left[\mathrm{kg} / \mathrm{m}^{2}\right](\mathrm{M} \pm \mathrm{SD})$ & $26.1 \pm 5.6$ & $26.7 \pm 4.4$ \\
\hline Waist circumference $[\mathrm{cm}](\mathrm{M} \pm \mathrm{SD})$ & $84.9 \pm 13.9$ & $94.8 \pm 11.8$ \\
\hline \multicolumn{3}{|l|}{ Blood pressure $[\mathrm{mm} \mathrm{Hg}](\mathrm{M} \pm \mathrm{SD})$} \\
\hline systolic & $128.8 \pm 20.6$ & $137.3 \pm 18.6$ \\
\hline diastolic & $81.2 \pm 11.3$ & $83.8 \pm 11.5$ \\
\hline Fasting blood glucose $[\mathrm{mg} / \mathrm{dl}](\mathrm{M} \pm \mathrm{SD})$ & $4.9 \pm 1.3$ & $5.1 \pm 1.6$ \\
\hline Triglycerides [mg/dl] $(\mathrm{M} \pm \mathrm{SD})$ & $115.0 \pm 77$ & $147.1 \pm 125$ \\
\hline High-density lipoprotein $[\mathrm{mg} / \mathrm{dl}](\mathrm{M} \pm \mathrm{SD})$ & $59.0 \pm 14.6$ & $52.0 \pm 14.9$ \\
\hline Metabolic syndrome [\%] & 33.1 & 25.9 \\
\hline \multicolumn{3}{|l|}{ Vitamin $\mathrm{D}[\mu \mathrm{g} / \mathrm{day}](\mathrm{M} \pm \mathrm{SD})$} \\
\hline intake & $2.5 \pm 2.9$ & $3.8 \pm 5.0$ \\
\hline supplements & $0.5 \pm 2.8$ & $0.3 \pm 2.3$ \\
\hline
\end{tabular}


Table 2 illustrates the associations between vitamin D intake and metabolic factors. Among women, there was an inverse correlation between vitamin D supplementation and the mean value of systolic blood pressure $(\mathrm{p}<0.05)$. No significant associations were found among men (Table 2).

Several correlations were observed after dividing the study group according to body mass index (BMI) (Table 3). Among obese women, there was a significant negative relationship between vitamin D supplementation and blood pressure $(\mathrm{p}<0.01)$, and a positive correlation between vitamin D consumption (dietary and total intake) and TG concentration. In men, there was a significant inverse correlation between vitamin D dietary intake and blood pressure $(\mathrm{p}<0.01)$, and a positive correlation with HDL-C concentration $(\mathrm{p}<0.05)$. In men with BMI $<30 \mathrm{~kg} / \mathrm{m}^{2}$, a negative relationship between vitamin $\mathrm{D}$ dietary intake and waist circumference was observed $(\mathrm{p}<0.05)$.

Additional regression analysis adjusted for age, sex, smoking, drinking alcohol, outdoor activity, diet and anti-hypertensive drugs was performed. However, there were no statistically significant correlations between vitamin D intake and waist circumference, blood pressure, fasting glucose and lipids (data not shown in Tables).

\section{DISCUSSION}

Whereas much is known about the harmful effects of low 25-hydroxyvitamin D levels, the role of increasing vitamin D intake, both dietary and by supplementation, has remained unresolved. The purpose of this study was to assess the relationship between vitamin D intake and supplementation, and the metabolic status of Polish adults.

Table 2. The correlation between vitamin D intake and supplementation, and metabolic disorders (Pearson's correlation index) in a representative sample of Polish adults participating in WOBASZ (2003-2005) and WOBASZ II (2013-2014) studies

\begin{tabular}{lcc}
\hline & Variable & \multicolumn{2}{c}{ Pearson's correlation coefficient } \\
\cline { 2 - 3 } & vitamin D dietary intake & vitamin D supplementation \\
\hline Women $(\mathrm{N}=1282)$ & & 0.026 \\
WC [cm] & -0.003 & $-0.080^{*}$ \\
SBP [mm Hg] & 0.006 & -0.032 \\
DBP [mm Hg] & 0.033 & 0.020 \\
TG [mg/dl] & -0.002 & -0.021 \\
HDL-C [mg/dl] & 0.028 & -0.010 \\
FG [mg/dl] & -0.028 & \\
Men (N = 1099) & & -0.026 \\
WC [cm] & -0.009 & -0.018 \\
SBP [mm Hg] & -0.038 & -0.039 \\
DBP [mm Hg] & -0.019 & -0.030 \\
TG [mg/dl] & 0.025 & -0.030 \\
HDL-C [mg/dl] & 0.022 & 0.014 \\
FG [mg/dl] & 0.024 & \\
\hline
\end{tabular}

$* \mathrm{p}<0.05 ; * * \mathrm{p}<0.01$.

DBP - diastolic blood pressure; FG - fasting blood glucose; HDL-C - high-density lipoprotein cholesterol; SBP - systolic blood pressure;

TG - triglycerides; WC - waist circumference. 
Table 3. The association between vitamin D intake and metabolic abnormalities according to BMI in a representative sample of Polish adults participating in WOBASZ (2003-2005) and WOBASZ II (2013-2014) studies

\begin{tabular}{|c|c|c|}
\hline & \multicolumn{2}{|c|}{ Pearson's correlation coefficient } \\
\hline & vitamin $\mathrm{D}$ dietary intake & vitamin D supplementation \\
\hline & \multicolumn{2}{|c|}{ Women } \\
\hline \multicolumn{3}{|c|}{$\mathrm{BMI}<30(\mathrm{~N}=970)$} \\
\hline $\mathrm{WC}[\mathrm{cm}]$ & 0.030 & -0.012 \\
\hline $\mathrm{SBP}[\mathrm{mm} \mathrm{Hg}]$ & 0.024 & -0.041 \\
\hline $\mathrm{DBP}[\mathrm{mm} \mathrm{Hg}]$ & 0.039 & -0.019 \\
\hline $\mathrm{TG}[\mathrm{mg} / \mathrm{dl}]$ & -0.017 & 0.017 \\
\hline $\mathrm{HDL}-\mathrm{C}[\mathrm{mg} / \mathrm{dl}]$ & 0.036 & 0.023 \\
\hline $\mathrm{FG}[\mathrm{mg} / \mathrm{dl}]$ & -0.013 & 0.021 \\
\hline \multicolumn{3}{|c|}{$\mathrm{BMI} \geq 30(\mathrm{~N}=303)$} \\
\hline $\mathrm{WC}[\mathrm{cm}]$ & -0.048 & -0.036 \\
\hline $\mathrm{SBP}[\mathrm{mm} \mathrm{Hg}]$ & -0.030 & $-0.181 * *$ \\
\hline $\mathrm{DBP}[\mathrm{mm} \mathrm{Hg}]$ & 0.043 & $-0.131^{*}$ \\
\hline $\mathrm{TG}[\mathrm{mg} / \mathrm{dl}]$ & $0.116^{*}$ & -0.014 \\
\hline $\mathrm{HDL}-\mathrm{C}[\mathrm{mg} / \mathrm{dl}]$ & -0.052 & -0.071 \\
\hline $\mathrm{FG}[\mathrm{mg} / \mathrm{dl}]$ & -0.066 & -0.088 \\
\hline \multicolumn{3}{|c|}{ Men } \\
\hline \multicolumn{3}{|c|}{$\mathrm{BMI}<30(\mathrm{~N}=850)$} \\
\hline $\mathrm{WC}[\mathrm{cm}]$ & $-0.071^{*}$ & -0.048 \\
\hline $\mathrm{SBP}[\mathrm{mm} \mathrm{Hg}]$ & -0.007 & -0.055 \\
\hline $\mathrm{DBP}[\mathrm{mm} \mathrm{Hg}]$ & 0.018 & -0.052 \\
\hline $\mathrm{TG}[\mathrm{mg} / \mathrm{dl}]$ & 0.025 & -0.036 \\
\hline $\mathrm{HDL}-\mathrm{C}[\mathrm{mg} / \mathrm{dl}]$ & 0.010 & -0.045 \\
\hline $\mathrm{FG}[\mathrm{mg} / \mathrm{dl}]$ & -0.003 & 0.008 \\
\hline \multicolumn{3}{|c|}{$\mathrm{BMI} \geq 30(\mathrm{~N}=235)$} \\
\hline $\mathrm{WC}[\mathrm{cm}]$ & -0.043 & -0.027 \\
\hline $\mathrm{SBP}[\mathrm{mm} \mathrm{Hg}]$ & $-0.174^{* *}$ & 0.053 \\
\hline $\mathrm{DBP}[\mathrm{mm} \mathrm{Hg}]$ & $-0.143^{*}$ & -0.040 \\
\hline $\mathrm{TG}[\mathrm{mg} / \mathrm{dl}]$ & 0.083 & 0.012 \\
\hline $\mathrm{HDL}-\mathrm{C}[\mathrm{mg} / \mathrm{dl}]$ & $0.133^{*}$ & 0.056 \\
\hline $\mathrm{FG}[\mathrm{mg} / \mathrm{dl}]$ & 0.054 & 0.061 \\
\hline
\end{tabular}

$* \mathrm{p}<0.05 ; * \mathrm{p}<0.01$.

Abbreviations as in Table 2. 
Poland, located in Central Europe, has a relatively low level of sunlight and, therefore, the adequate vitamin D intake (both dietary and by supplementation) seems particularly important. According to Manios et al., vitamin D deficiency, a 25(OH)D concentration of $30 \mathrm{nmol} / \mathrm{l}$ was observed in $2.5 \%$ while vitamin $\mathrm{D}$ insufficiency, a $25(\mathrm{OH}) \mathrm{D}$ concentration of $30-49.9 \mathrm{nmol} / \mathrm{l}$, in $34 \%$ of Polish adults [28].

A major finding of the present paper is that the significant relationship between vitamin D intake and metabolic risk factors may depend on the obesity status. Substantial correlations were found mainly among individuals with BMI $\geq 30 \mathrm{~kg} / \mathrm{m}^{2}$. The most probable explanation for the significant results limited to persons with excess weight may be the fact that obesity is often associated with lower $25(\mathrm{OH}) \mathrm{D}$ concentrations in comparison to normal-weight individuals $[22,29,30]$.

The most important relationship was observed in the context of blood pressure regardless of gender. The authors found that vitamin D intake was inversely associated with systolic and diastolic blood pressure in obese individuals. These results are in line with numerous studies demonstrating the negative relationship between blood pressure, vitamin D intake and circulating 25(OH)D [31-33]. Pfeifer et al. noticed a $9 \%$ decrease in systolic blood pressure after vitamin D and calcium supplementation [34]. Al-Dujalili et al. also highlighted an effect of vitamin D consumption on both systolic and diastolic blood pressure [35]. In contrast, some studies have shown no beneficial relationships in this context [36-40]. For example, Salekzamani et al. showed that supplementation with high-dose vitamin D for 4 months was not correlated with blood pressure [41]. Interestingly, Rejnmark et al. performed a systematic quantitative review on the characteristics of randomized clinical trials included in meta-analyses on the non-skeletal effects of vitamin D supplementation. Generally, most results of the analyzed trials did not show any beneficial effects of vitamin D intake on several health outcomes. Vi- tamin D supplementation as an important anti-hypertensive strategy was reported only in 2/9 meta-analyses [42]. However, those trials were mostly performed in populations without low $25(\mathrm{OH}) \mathrm{D}$ levels.

Several studies have shown that subjects with the adequate serum $25(\mathrm{OH}) \mathrm{D}$ concentration and high vitamin D intake have a more favorable lipid profile than those with vitamin D deficiency [3,22,41,43-46]. The most often observed changes include a vitamin $\mathrm{D}$-induced decrease in triglycerides and an increase in HDL-C. In the present paper, the positive relationship between vitamin $\mathrm{D}$ intake and HDL-C in men is in line with other authors' reports $[47,48]$. However, a few studies have revealed unfavorable serum lipid profiles in subjects with high serum $25(\mathrm{OH}) \mathrm{D}$ levels or due to vitamin D administration. A significant increase in low-density-lipoprotein cholesterol (LDL-C) in groups taking vitamin D supplements, as compared to the placebo group, was observed [49,50]. Moreover, Tabesh et al. [47] showed a positive association between $25(\mathrm{OH}) \mathrm{D}$ and $\mathrm{TG}$ levels in young women. In the present study, the authors noticed a positive correlation between dietary vitamin D intake and triglycerides concentration in obese women. The most probable explanation may be particular susceptibility of obese postmenopausal women to metabolic disorders (especially lipid disorders) due to vitamin D deficiency [43].

Quite unexpectedly, no substantial associations were found between vitamin D intake and glucose concentration. Although several studies have demonstrated beneficial effects of a higher vitamin D intake or the serum 25(OH)D level [15,51], some researchers have reported no significant relationships [16,18,41,52,53]. Based on the present findings, it seems possible that vitamin D may not be strongly associated with glucose metabolism in a population with relatively low fasting glucose levels.

The results obtained in this study show that dietary vitamin D intake in Poland is relatively low and far from the Estimated Average Requirement value of $10 \mu \mathrm{g} /$ day, 
as recently proposed by the Institute of Medicine Dietary Reference Intake Committee. Vitamin D intake is lower in women, which is in line with findings obtained for the participants of the Food4Me study [28]. The prevalence of vitamin D supplementation in Poland is also low, with only $4.4 \%$ of women and $2.6 \%$ of men reporting regular vitamin D supplementation. Taking into account that dietary supplements are thought to be the second most effective strategy to counteract vitamin D deficiency, a more intensive promotion of vitamin D supplementation in adequate doses seems of particular importance. A study by Manios et al. has revealed that vitamin $\mathrm{D}$ intakes of at least $10 \mu \mathrm{g} /$ day from foods and/or supplements can ensure sufficient 25(OH)D concentrations [28].

Some shortcomings of this paper should be recognized. The study is limited by its cross-sectional design which does not enable determining definite causal relationships. As far as the dietary recall is concerned, the fortified food was not taken into account in the assessment of vitamin D intake. Additionally, performing a repeated 24-h dietary recall would probably make the estimations more accurate. Moreover, the serum 25(OH)D level was not measured in the WOBASZ projects and, thus, the correlation between the level of vitamin $\mathrm{D}$ and metabolic disorders could not be assessed. Due to the observed low prevalence of vitamin D supplementation, the findings revealed in this group should be interpreted with caution. Another important limitation concerns the method of measuring waist circumference. Although both the WHO and the IDF recommend the measurement at the midpoint between the iliac crest and the lowest rib, other sites are also commonly adopted. As the WOBASZ project is a large population study, the authors decided to measure WC at the umbilicus which seems the most intuitive and easy method. Finally, the synthesis of vitamin D in the skin, triggered by sun exposure, was not considered.

The distinct strength of the study is the large number of participants randomly selected from the national regis- ter. Therefore, the obtained findings are representative of adults in Poland. Regarding metabolic risk factors, all the measurements were performed by qualified nurses. Data on dietary habits were collected via face-to-face interviews performed by trained interviewers. These findings could be of particular importance for other middleincome countries.

\section{CONCLUSIONS}

The findings presented by the authors suggest that the correlation between vitamin $\mathrm{D}$ intake and metabolic risk factors may depend on the obesity status. A higher vitamin D intake (dietary or by supplements) may reduce BP and increase HDL-C in obese subjects. The positive relationship between vitamin D intake and TG concentration in women needs further investigation.

\section{REFERENCES}

1. Lips P, van Shoor NM, de Jongh RT. Diet, sun, and lifestyle as determinants of vitamin D status. Ann N Y Acad Sci. 2014;1317:92-8, https://doi.org/10.1111/nyas.12443.

2. DeLuca HF. Overview of general physiologic features and functions of vitamin D. Am J Clin Nutr. 2004;80 Suppl 6: 1689S-96S, https://doi.org/10.1093/ajcn/80.6.1689S.

3. Muñoz-Aguirre P, Denova-Gutiérrez E, Flores M, SalazarMartinez E, Salmerón J. High vitamin D consumption is inversely associated with cardiovascular disease risk in an urban Mexican population. PLoS One. 2016;11(11):e0166869, https://doi.org/10.1371/journal.pone.0166869.

4. Ghanei L, Ziaee A, Rostami P, Oveisi S, Esmailzadehha N, Kazemifar AM, et al. Association of serum 25-hydroxyvitamin D levels and vitamin D dietary intake with metabolic syndrome: a case control study. J Res Health Sci. 2015;15(1):32-6.

5. Vanlint S. Vitamin D and obesity. Nutrients. 2013;5(3):94956, https://doi.org/10.3390/nu5030949.

6. Pham TM, Ekwaru JP, Loehr SA, Veugelers PJ. The relationship of serum 25-hydroxyvitamin D an insulin resistance among nondiabetic Canadians: a longitudinal analysis 
of participants of a preventive health program. PLoS One. 2015;10(10):e0141081, https://doi.org/10.1371/journal.pone.01 41081.

7. Muscogiuri G, Annweiler C, Duval G, Karras S, Tirabassi G, Salvio G, et al. Vitamin D and cardiovascular disease: from atherosclerosis to myocardial infarction and stroke. Int J Cardiol. 2017;230:577-84, https://doi.org/10.1016/j.ijcard.2016.12.053.

8. Hosseinpanah F, Yarjanli M, Sherikholeslami F, Heibatollahi M, Eskandary PS, Azizi F. Associations between vitamin D and cardiovascular outcomes; Tehran Lipid and Glucose Study. Atherosclerosis. 2011;218(1):238-42, https://doi.org/ 10.1016/j.atherosclerosis.2011.05.016.

9. Khan H, Kunutsor S, Franco OH, Chowdhury R. Vitamin D, type 2 diabetes and other metabolic outcomes: a systematic review and meta-analysis of prospective studies. Proc Nutr Soc. 2013;72(1):89-97, https://doi.org/10.1017/S002966 5112002765 .

10. Maki KC, Fulgoni VL 3rd, Keast DR, Rains TM, Park KM, Rubin MR. Vitamin D intake and status are associated with lower prevalence of metabolic syndrome In U.S. adults: National Health and Nutrition Examination Surveys 2003-2006. Metab Syndr Relat Disord. 2012;10(5):363-72.

11. Breslavsky A, Frand J, Matas Z, Boaz M, Barnea Z, Shargorodsky M. Effect of high doses of vitamin D on arterial properties, adiponectin, leptin and glucose homeostasis in type 2 diabetic patients. Clin Nutr. 2013;32(6):970-75, https:// doi.org/10.1016/j.clnu.2013.01.020.

12. Ryu OH, Lee S, Yu J, Choi MG, Yoo HJ, Mantero F. A prospective randomized controlled trial of the effects of vitamin $\mathrm{D}$ supplementation on long-term glycemic control in type 2 diabetes mellitus of Korea. Endocr J. 2014;61(2):167-76.

13. Wood AD, Secombes KR, Thies F, Aucott L, Black AJ, Mavroeidi A, et al. Vitamin D3 supplementation has no effect on conventional cardiovascular risk factors: a parallelgroup, double-blind, placebo-controlled RCT. J Clin Endocrinol Metab. 2012;97(10):3557-68, https://doi.org/10.1210/ jc.2012-2126.
14. Major GC, Alarie F, Doré J, Phouttama S, Tremblay A. Supplementation with calcium+vitamin D enhances the beneficial effect of weight loss on plasma lipid and lipoprotein concentrations. Am J Clin Nutr. 2017;85(1):54-9.

15. Von Hurst PR, Stonehouse W, Coad J. Vitamin D supplementation reduces insulin resistance in South Asian women living in New Zealand who are insulin resistant and vitamin D deficient - a randomised, placebo-controlled trial. $\mathrm{Br}$ J Nutr. 2010;103(4):549-55, https://doi.org/10.1017/S00071 14509992017.

16. Ramly M, Ming MF, Chinna K, Suboh S, Pendek R. Effect of vitamin D supplementation on cardiometabolic risks and health-related quality of life among urban premenopausal women in a tropical country - a randomized controlled trial. PLoS One. 2014;9(10):e110476, https://doi.org/10.1371/journal.pone.0110476.

17. Witham MD, Adams F, Kabir G, Kennedy G, Belch JJ, Khan F. Effect of short-term vitamin D supplementation on markers of vascular health in South Asian women living in the UK - a randomised controlled trial. Atherosclerosis. 2013;230(2):293-9, https://doi.org/10.1016/j.atherosclerosis. 2013.08.005.

18. Ryu OH, Chung W, Lee S, Hong KS, Choi MG, Yoo HJ. The effect of high-dose vitamin D supplementation on insulin resistance and arterial stiffness In patients with type 2 diabetes. Korean J Intern Med. 2014;29(5):620-9, https://doi. org/10.3904/kjim.2014.29.5.620.

19. Guo J, Cockcroft JR, Elwood PC, Pickering JE, Lovegrove JA, Givens DI. Vitamin D intake and risk of CVD and all-cause mortality: evidence from the Caerphilly Prospective Cohort Study. Public Health Nutr. 2017;20(15):2744-53, https://doi.org/10.1017/S1368980017001732.

20. Shab-Bidar S, Neyestani TR, Djazayery A, Eshraghian MR, Houshiarrad A, Gharavi A, et al. Regular consumption of vitamin D-fortified yogurt drink (Doogh) improved endothelial biomarkers in subjects with type 2 diabetes: a randomized double-blind clinical trial. BMC Med. 2011;9:125, https://doi.org/10.1186/1741-7015-9-125. 
21. Salehpour A, Hosseinpanah F, Shidfar F, Vafa M, Razaghi M, Dehghani S, et al. A 12-week double-blind randomized clinical trial of vitamin D3 supplementation on body fat mass in healthy overweight and obese women. Nutr J. 2012;11:78, https://doi.org/10.1186/1475-2891-11-78.

22. Alefishat E, Abu Farha R. Determinants of vitamin D status among Jordanian employees: Focus on the night shift effect. Int J Occup Med Environ Health. 2016;29(5):859-70, https://doi.org/10.13075/ijomeh.1896.00657.

23. Broda G, Rywik S. Multicenter national polish population health status tests WOBASZ project. Establishment of methods and logistics. Kardiol Pol. 2005;63(6):601-4.

24. Drygas W, Niklas AA, Piwońska A, Piotrowski W, Flotyńska A, Kwaśniewska M, et al. Multicenter National Population Health Examination Survey (WOBASZ II study): assumptions, methods and implementation. Kardiol Pol. 2016;74(7):681-90, https://doi.org/10.5603/KP.a2015.0235.

25. WHO MONICA Project, Monica Manual, revised edition. Geneva: Cardiovascular Disease Unit, WHO; 1990.

26. Kunachowicz H, Przygoda B, Nadolna I, Iwanow K. [Tables of nutritional values of food]. Warszawa: PZWL; 2005. Polish.

27. Alberti KG, Eckel RH, Grundu SM, Zimmet PZ, Cleeman JI, Donato KA, et al. Harmonizing the metabolic syndrome: a joint interim statement of the International Diabetes Federation Task Force on Epidemiology and Prevention; National Heart, Lung, and Blood Institute; American Heart Association; World Heart Federation; International Atherosclerosis Society; and International Association for the Study of Obesity. Circulation. 2009;120(16):1640-5, https:// doi.org/10.1161/CIRCULATIONAHA.109.192644.

28. Manios Y, Moschonis G, Lambrinou CP, Mavrogianni C, Tsirigoti L, Hoeller U, et al. Associations of vitamin D status with dietary intakes and physical activity levels among adults from seven European countries: the Food4Me Study. Eur J Nutr. 2018;57(4):1357-68, https://doi.org/10.1007/s00394-017-1415-1.

29. Blum M, Dolnikowski G, Seyoum E, Harris SS, Booth SL, Peterson J, et al. Vitamin D3 in fat tissue. Endocrine. 2008;33(1):90-4, https://doi.org/10.1007/s12020-008-9051-4.
30. Wortsman J, Matsuoka L, Chen TC, Lu Z, Holick MF. Decreased bioavailability of vitamin D in obesity. Am J Clin Nutr. 2000;72(3):690-3.

31. Weng S, Sprague JE, Oh J, Riek AE, Chin K, Garcia M, et al. Vitamin D deficiency induces high blood pressure and accelerates atherosclerosis in mice. PLoS One. 2013;8(1):e54625, https://doi.org/10.1371/journal.pone.0054625.

32. Judd SE, Nanes MS, Ziegler TR, Wilson PW, Tangpricha V. Optimal vitamin D status attenuates the age-associated increase in systolic blood pressure in white Americans: results from the third National Health and Nutrition Examination Survey. Am J Clin Nutr. 2008;87(1):136-41.

33. Mirhosseini N, Vatanparast H, Kimball SM. The Association between Serum 25(OH)D Status and Blood Pressure in Participants of a Community-Based Program Taking Vitamin D Supplements. Nutrients. 2017;9(11):1244, https://doi.org/10. 3390/nu9111244.

34. Pfeifer M, Begerow B, Minne HW, Cachtigall D, Hansen C. Effects of a short-term vitamin D3 supplementation on blood pressure and parathyroid hormone levels in elderly women. J Clin Endocrinol Metab. 2001;86(4):1633-7.

35. Al-Dujalili EA, Munir N, Iniesta RR. Effect of vitamin D supplementation on cardiovascular disease risk factors and exercise performance in healthy participants: a randomized placebo-controlled preliminary study. Ther Adv Endocrinol Metab. 2016;7(4):153-65, https://doi.org/10.1177/ 2042018816653357.

36. Wood AD, Secombes KR, Thies F, Aucott L, Black AJ, Mavroeidi A, et al. Vitamin D3 supplementation has no effect on conventional cardiovascular risk factors: a parallel-group, double-blind, placebo-controlled RCT. J Clin Endocrinol Metab. 2012;97(10):3557-68, https://doi.org/10.1210/jc.2012-2126.

37. Wamberg L, Kampmann U, Stødkilde-Jørgensen H, Rejnmark L, Pedersen SB, Richelsen B. Effects of vitamin D supplementation on body fat accumulation, inflammation, and metabolic risk factors in obese adults with low vitamin D levels- results from a randomized trial. Eur J Intern Med. 2013;24(7):644-9, https://doi.org/10.1016/j.ejim.2013.03.005. 
38. Tomson J, Hin H, Emberson J, Kurien R, Lay M, Cox J, et al. Effects of Vitamin D on Blood Pressure, Arterial Stiffness, and Cardiac Function in Older People After 1 Year: BEST-D (Biochemical Efficacy and Safety Trial of Vitamin D). J Am Heart Assoc. 2017;6(10), https://doi.org/10.1161/JAHA.117. 005707.

39. Arora P, Song Y, Dusek J, Plotnikoff G, Sabatine MS, Cheng S, et al. Vitamin D therapy in individuals with prehypertension and hypertension: the DAYLIGHT trial. Circulation. 2015;131(3):254-62, https://doi.org/10.1161/CIRCULATIONAHA.114.011732.

40. Scragg R, Stewart AW, Waayer D, Lawes CMM, Toop L, Skuyter J, et al. Effect of Monthly High-Dose Vitamin D Supplementation on Cardiovascular Disease in the Vitamin D Assessment Study: A Randomized Clinical Trial. JAMA Cardiol. 2017;2(6):608-16, https://doi.org/10.1001/jamacardio.2017.0175.

41. Salekzamani S, Mehralizadeh H, Ghezel A. Effect of highdose vitamin D supplementation on cardiometabolic risk factors In subjects with metabolic syndrome: a randomized controlled double-blind clinical trial. J Endocrinol Invest. 2016;39(11):1303-13.

42. Rejnmark L, Bislev LS, Cashman KD, Eriksdottir G, Gaksch M, Grübler M, et al. Non-skeletal health effects of vitamin D supplementation: A systematic review on finding from meta-analyses summarizing trial data. PLoS One. 2017;12(7):e0180512, https://doi.org/10.1371/journal.pone. 0180512.

43. Schmitt EB, Nahas-Neto J, Bueloni-Dias F, Poloni PF, Orsatti CL, Petri Nahas EA. Vitamin D deficiency is associated with metabolic syndrome in postmenopausal women. Maturitas. 2018;107:97-102, https://doi.org/10.1016/j.maturitas. 2017.10.011.

44. Martins D, Wolf M, Pan D, Zadshir A, Tareen N, Thadhani R, et al. Prevalence of cardiovascular risk factors and the serum levels of 25-hydroxyvitamin D in the United States: data from the Third National Health and Nutrition Examination Survey. Arch Intern Med. 2007;167(11):1159-65.
45. Glueck CJ, Jetty V, Rothschild M, Duhon G, Shah P, Prince M, et al. Associations between Serum 25-hydroxyvitamin D and Lipids, Lipoprotein Cholesterols, and Homocysteine. N Am J Med Sci. 2016;8(7):284-90, https://doi. org/10.4103/1947-2714.187137.

46. Kang JY, Kim MK, Jung S, Shin J, Choi BY. The crosssectional relationships of dietary and serum vitamin D with cardiometabolic risk factors: Metabolic components, subclinical atherosclerosis, and arterial stiffness. Nutrition. 2016;32(10):1048-56, https://doi.org/10.1016/j.nut. 2016.02.019.

47. Tabesh M, Callegari ET, Gorelik A, Garland SM, Nankervis A, Subasinghe AK, et al. Associations between 25-hydroxyvitamin D levels, body composition and metabolic profiles in young women. Eur J Clin Nutr. 2018;72(8):1093-102, https://doi.org/10.1038/s41430-018-0086-1.

48. Jorde R, Figenschau Y, Hutchinson M, Emaus N, Grimnes G. High serum 25-hydroxyvitamin D concentrations are associated with a favorable serum lipid profile. Eur J Clin Nutr. 2010;64(12):1457-64, https://doi.org/10.1038/ejcn. 2010.176 .

49. Zitterman A, Frisch S, Berthold HK, Götting C, Kuhn J, Kleesiek K, et al. Vtamin D supplementation enhances the beneficial effects of weight loss on cardiovascular disease risk markers. Am J Clin Nutr. 2009;89(5):1321-7, https://doi. org/10.3945/ajcn.2008.27004.

50. Salehpour A, Shidfar F, Hosseinpanah F, Vafa M, Razaghi M, Hoshiarrad A, et al. Vitamin D3 and the risk of CVD in overweight and obese women: a randomized controlled trial. Br J Nutr. 2012;108(10):1866-73, https://doi. org/10.1017/S0007114512000098.

51. Yousefi Rad E, Djalali M, Koohdani F, Saboor-Yaraghi AA, Eshraghian MR, Javanbakht MH, et al. The Effects of Vitamin D Supplementation on Glucose Control and Insulin Resistance in Patients with Diabetes Type 2: A Randomized Clinical Trial Study. Iran J Public Health. 2014;43(12):1651-6. 52. Sollid ST, Hutchinson MY, Fuskevåg OM, Figenschau Y, Joakimsen RM, Schirmer H, et al. No effects of high-dose 
vitamin D supplementation on glycemic status or cardiovascular risk factors in subjects with prediabetes. Diabetes Care. 2014;37(8):2123-31, https://doi.org/10.2337/dc14-0218.

53. Gulseth HL, Wium C, Angel K, Eriksen EF, Birkeland KI. Effects of vitamin D supplementation on Insulin Sensitiv- ity and Insulin Secretion in Subjects With Type 2 Diabetes and Vitamin D Deficiency: A randomized Controlled Trial. Diabetes Care. 2017;40(7):872-8, https://doi.org/10.2337/dc 16-2302.

This work is available in Open Access model and licensed under a Creative Commons Attribution-NonCommercial 3.0 Poland License - http://creativecommons.org/ licenses/by-nc/3.0/pl/deed.en. 